\title{
Electrocatalytic and Voltammetric Determination of Sulfhydryl Compounds Through Iron Nitroprusside Modified Graphite Paste Electrode
}

\author{
Devaney R. do Carmo, Ricardo M. da Silva and Nelson R. Stradiotto* \\ Instituto de Química, Universidade Estadual Paulista, CP 355, 14801-970 Araraquara - SP, Brazil
}

\begin{abstract}
O Nitroprussiato de ferro, Fe(II)NP foi incorporado em um eletrodo de pasta de grafite, sendo os estudos eletroquímicos realizados empregando a técnica de voltametria cíclica. O voltamograma cíclico de Fe(II)NP exibiu dois pares redox com potencial formal $\left(\mathrm{E}^{0^{\prime}}\right)_{1}=0,24 \mathrm{e}\left(\mathrm{E}^{0^{\prime}}\right)_{2}=0,85 \mathrm{~V} v$ s. $\mathrm{SCE}$ atribuídos a $\mathrm{Fe}^{(\mathrm{II})} / \mathrm{Fe}^{(\mathrm{III})}$ e $\mathrm{Fe}^{(\mathrm{II})}(\mathrm{CN})_{5} \mathrm{NO} / \mathrm{Fe}^{(\mathrm{III})}(\mathrm{CN})_{5} \mathrm{NO}$, respectivamente. O par redox com $\left(\mathrm{E}^{0^{\prime}}\right)_{2}=0,85 \mathrm{~V}$ apresentou uma resposta eletrocatalítica para os compostos sulfidrílicos; L-cisteína e $\mathrm{N}$-acetylcisteína. A oxidação eletrocatalítica dos compostos sulfidrílicos pelo mediador foi empregada para a determinação de L-cisteína e $\mathrm{N}$-acetilcisteína. O eletrodo de pasta de grafite modificado para a determinação de L-cisteína e $\mathrm{N}$-acetilcisteína apresenta uma linearidade de 9,2 $\times 10^{-4}-2,0 \times 10^{-2} \mathrm{e}$ $9,6 \times 10^{-4}-1,4 \times 10^{-2} \mathrm{~mol} \mathrm{~L}^{-1}$ com limite de detecção de $1,9 \times 10^{-4} \mathrm{~mol} \mathrm{~L}^{-1}$ e $1,5 \times 10^{-4} \mathrm{~mol} \mathrm{~L}^{-1}$ e desvio padrão relativo de \pm 5 e $4 \%(\mathrm{n}=3)$ e sensibilidade amperométrica de 0,024 e $0,027 \mu \mathrm{A} / \mu \mathrm{mol} \mathrm{L}{ }^{-1}$. A aplicação deste eletrodo foi testada determinando-se $\mathrm{N}$ - acetilcisteína em um fármaco (Fluimucil).
\end{abstract}

Iron nitroprusside $\mathrm{Fe}$ (II)NP was incorporated into a carbon paste electrode and the electrochemical studies were performed with cyclic voltammetry. The cyclic voltammogram of Fe(II)NP exhibits two redox couple with formal potential $\left(\mathrm{E}^{0^{\prime}}\right)_{1}=0.24 \mathrm{e}\left(\mathrm{E}^{0^{\prime}}\right)_{2}=0.85 \mathrm{~V} v s \mathrm{SCE}$ attributed to $\mathrm{Fe}^{(\mathrm{II})} / \mathrm{Fe}^{(\mathrm{II})}$ and $\mathrm{Fe}^{(\mathrm{II})}(\mathrm{CN})_{5} \mathrm{NO} / \mathrm{Fe}^{(\mathrm{III})}(\mathrm{CN})_{5} \mathrm{NO}$, respectively. The redox couple with $\left(\mathrm{E}^{0}\right)_{2}=0.85 \mathrm{~V}$ presents an electrocatalytic response for sulfhydryl compounds. The electrocatalytic oxidation of sulfhydryl compounds by the mediator has been used for the determination of L-cysteine and $\mathrm{N}$-acetylcysteine. The modified graphite paste electrode gives a linear range from $9.2 \times 10^{-4}-2.0 \times 10^{-2} ; 9.6 \times 10^{-4}-$ $1.4 \times 10^{-2} \mathrm{~mol} \mathrm{~L}^{-1}$ for the determination of L-cysteine and $\mathrm{N}$-acetylcysteine, respectively, with detection limit of $1.9 \times 10^{-4} \mathrm{~mol} \mathrm{~L}^{-1} ; 1.5 \times 10^{-4} \mathrm{~mol} \mathrm{~L}^{-1}$ and relative standard desviations $\pm 5 \%$ and $1.5 \times 10^{-3}$ $\mathrm{mol} \mathrm{L}{ }^{-1} \pm 4 \%(\mathrm{n}=3)$. The amperometric sensitivities are 0.024 and $0.027 \mu \mathrm{A} / \mu \mathrm{mol} \mathrm{L}^{-1}$ for L-cysteine and $\mathrm{N}$-acetylcysteine, respectively. The application of this electrode was tested and a commercial pharmaceutical product (Fluimucil) has been determined.

Keywords: iron nitroprusside, graphite paste electrode, L-cysteine, $\mathrm{N}$-acetylcysteine, sulfhydryl compounds

\section{Introduction}

The chemical modification of electrodes is a field of growing interest in analytical chemistry. In electrochemistry, it has been demonstrated that chemically modified electrodes possess distinct advantages over conventional electrodes in numerous application areas including electrocatalysis and electrochemical sensors. ${ }^{1-7}$ One of the important properties of the chemical modified electrodes (CMEs), which has been the subject of considerable study, is their ability to catalyze the oxidation and reduction of solute species which exhibit high overpotential at

* e-mail: nrstradi@iq.unesp.br unmodified electrode surfaces. The CMEs offer a possibility of lowering the overpotential and increasing sensitivity and selectivity of some electroactives species. In addition, they possess distinct advantages over mercury electrodes due to their possible toxicity or because of rapid deterioration of electrode response. ${ }^{8}$ Platinum and gold electrodes form surface oxides, also causing complications with analytical applications. ${ }^{9}$ From this point of view the graphite paste electrode offers advantages over the above mentioned methods.

One important group of inorganic compounds used for modification of graphite are the transition metal cyanoferrates in view of their well known catalytic activity. ${ }^{10-15}$ Metal nitroprusside films are not of easy preparation and 
these films are difficult to reproduce. The last proposition explains the small number of works in the literature and the different viewpoints among the authors. ${ }^{16}$ This work suggests the use of modified graphite paste electrode with iron nitroprusside for electrochemical studies. Characterization and electrochemical behavior of Fe(II)NP have been recently reported. ${ }^{17}$ In a second part of theses studies, we will describe the electrocatalytic properties of graphite paste electrode modified with iron nitroprusside as a mediator for oxidation of L-cysteine and $\mathrm{N}$-acetylcysteine. These sulfhydryl compounds play very important role in living systems. As a direct application of the electrocatalytic properties of iron nitroprusside, $\mathrm{N}$-acetylcysteine was determined in a pharmaceutical product (Fluimucil).

\section{Experimental}

\section{Chemical reagents}

L- cysteine hydrochloride monohydrate (L-cys) and $\mathrm{N}$ - acetylcysteine $(\mathrm{N}$-acy) were used without further purification. All reagents and solvents were of analytical grade (Merck or Aldrich) and were used as purchased. All solutions and supporting electrolytes were prepared using Milli-Q water.

The L-cys and $\mathrm{N}$-acy solutions were prepared immediately before use and were dearated with purified nitrogen. This procedure was adopted because this species can be oxidized to cystine and $\mathrm{N}$-aceltylcystine, respectively, by atmospheric oxygen.

\section{Measurements}

Cyclic voltammetry was performed using an Auto Lab equipment (PGSTAT 30-Eco chemie). The three electrode system used in these studies consisted of a modified working electrode (modified graphite paste electrode), a SCE reference electrode and a platinum wire as the auxiliary electrode.

\section{Preparation of $\mathrm{Fe}(\mathrm{II}) \mathrm{NP}$}

The preparation and characterization of $\mathrm{Fe}(\mathrm{II}) \mathrm{NP}$ have been reported recently. ${ }^{17}$ A $0.05 \mathrm{~mol} \mathrm{~L}^{-1}$ solution of $\mathrm{Fe}\left(\mathrm{NH}_{3}\right) \mathrm{SO}_{4}$, was added in slight excess to a $0.05 \mathrm{~mol} \mathrm{~L}^{-1}$ solution of commercially available $\mathrm{Na}_{2}\left[\mathrm{Fe}(\mathrm{CN})_{5} \mathrm{NO}_{2} \mathrm{H}_{2} \mathrm{O}\right.$. The $\mathrm{pH}$ of the solution was adjusted ( $\mathrm{pH} \sim 3.0$ ) in order to prevent formation of $\mathrm{Fe}$ (II) hydroxide. The precipitates obtained were left overnight for aging, collected by filtration or centrifugation, washed with distilled water until sulfate ion could not be detected in the filtrate, finally washed with $95 \%$ ethanol, and dried over calcium chloride to constant weight.

\section{Preparation of the graphite paste electrode modified with $\mathrm{Fe}(\mathrm{II}) \mathrm{NP}$}

The graphite paste electrode modified with Fe(II)NP was prepared by mixing $10 \mathrm{mg}$ of $\mathrm{Fe}(\mathrm{II}) \mathrm{NP}$ with $90 \mathrm{mg}$ of graphite (Aldrich) and $50 \mu \mathrm{L}$ of mineral oil. The graphite paste with $\mathrm{Fe}(\mathrm{II}) \mathrm{NP}$ was included in a cavity with $2 \mathrm{~mm}$ inner diameter, connected with a copper wire.

\section{Procedure}

Initially, cyclic voltamograms were recorded for study the electrocatalysis of L- cysteine and $\mathrm{N}$-acetylcysteine by graphite paste electrode modified with iron nitroprusside. The L-cysteine and $\mathrm{N}$-acetylcysteine solutions were prepared immediately before use and were deaerated with nitrogen. In most of the experiments, $1.0 \mathrm{~mol} \mathrm{~L}^{-1} \mathrm{KCl}(\mathrm{pH} \sim 6.8$ ) was used as the supporting electrolyte. The catalytic current was estimated by the difference between the electrode current in the presence of sulfhydryl compounds and that which is established in the blank solution.

\section{Procedure for the voltammetric determination of Fluimucil}

In this study, we have applied the modified electrode to the determination of $\mathrm{N}$-acetylcysteine in a pharmaceutical product (Fuimucil).

A standard aqueous solution of $\mathrm{N}$ - acetylcysteine $0.101 \mathrm{~mol} \mathrm{~L}^{-1}$ (stock solution) was preparated in water.

One commercial tablet $(5.0348 \mathrm{~g})$ was dissolved in water $(25 \mathrm{~mL})$. The standard addition method was employed for the quantification of Fluimucil. In an electrochemical cell filled with $20 \mathrm{~mL} 1.0 \mathrm{~mol} \mathrm{~L}^{-1} \mathrm{KCl}$, suitable aliquots $(500 \mu \mathrm{L})$ were immediately added to the cell and the curves were registered after successive addition of $200 \mu \mathrm{L}$ of the standard solution of the sample. The experiments were done in triplicate.

\section{Results and Discussion}

The electrochemical behavior of iron nitroprusside modified graphite paste electrode, already described in report recent, ${ }^{17}$ exhibits two redox couples. The electrocatalysis of graphite paste electrode modified with $\mathrm{Fe}(\mathrm{II}) \mathrm{NP}$ for electro-oxidation of L-cys and $\mathrm{N}$-acy in a $1.0 \mathrm{~mol} \mathrm{~L}^{-1}$ $\mathrm{KCl}$ solution is showed in Figures 1 and 2. It can be seen 
that the electrochemical behavior of L-cysteine and $\mathrm{N}$ acetylcysteine is similar.

Figures 1 and 2 show cyclic voltammograms of Fe(II)NP in absence (curve c) and presence (curve d) of L-cysteine and $\mathrm{N}$-acetylcysteine respectively. The carbon paste electrode displays no redox peaks in the potential range from -0.3 to $1.2 \mathrm{~V}$ in absence or presence of sulfhydryl compounds (see curves a and $b$, respectively). After the addition of these sulfhydryl compounds, a substantial enhancement of the anodic peak current is observed (curve d). The peak current increased in proportion to the analyte concentration. This increase in anodic current indicates the electrocatalytic oxidation of sulphydril compound by the Fe(II)NP mediator. The Fe(III) produced during the anodic scan chemically oxidizes sulfhydryl compounds while it is reduced to $\mathrm{Fe}(\mathrm{II})$, which will be again electrochemically oxidized to Fe(III).

The electrochemical oxidation of L-cysteine ${ }^{18}$ can be written as:

2 L-cysteine $(\mathrm{CySH})-2 \mathrm{e}^{-}-2 \mathrm{H}^{+} \longrightarrow$ Cystine (CySSCy)

Sulfhydryl oxidation reactions at the iron nitropruside modified paste electrode electrode interface can be described by the following reactions:

$\left.\left.\mathrm{Fe}^{\mathrm{II}}\left[\mathrm{Fe}^{\mathrm{II}} \mathrm{CN}\right)_{5} \mathrm{NO}\right]-1 \mathrm{e}^{-} \rightleftarrows \mathrm{Fe}^{\mathrm{III}}\left[\mathrm{Fe}^{\mathrm{II}} \mathrm{CN}\right)_{5} \mathrm{NO}\right]($ at $0.24 \mathrm{~V}$ )

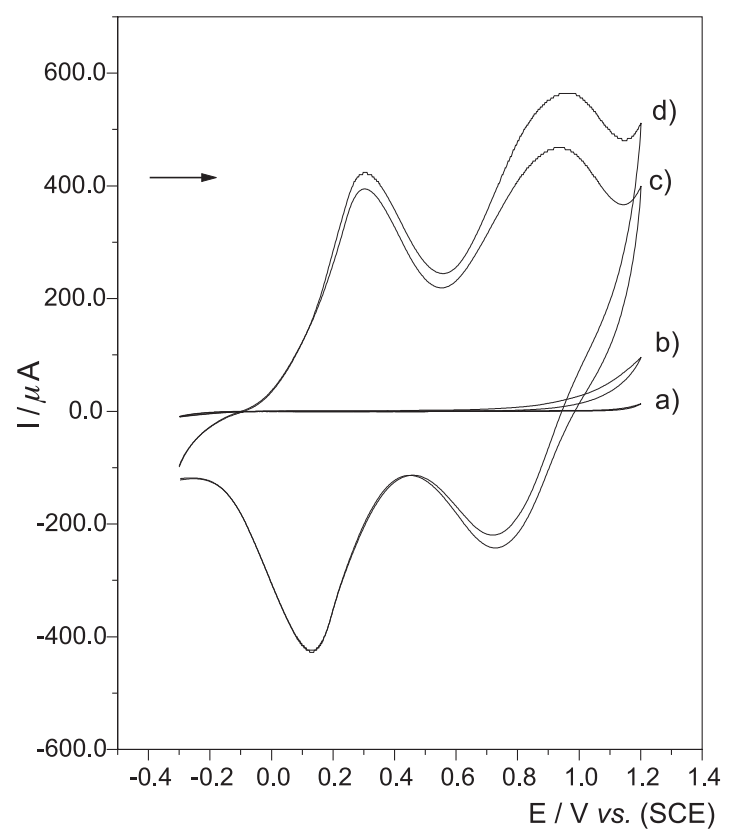

Figure 1. Cyclic voltammogram of: a) graphite paste electrode; b) graphite paste electrode with $2.9 \times 10^{-2} \mathrm{~mol} \mathrm{~L}^{-1} \mathrm{~L}$-cysteine; c) iron nitroprusside modified graphite paste electrode (Fe(II)NP); d) modified electrode with $2.9 \times 10^{-2} \mathrm{~mol} \mathrm{~L}^{-1} \mathrm{~L}$-cysteine $\left(1.0 \mathrm{~mol} \mathrm{~L}^{-1} \mathrm{KCl}\right.$; $\mathrm{v}=20 \mathrm{mV} \mathrm{s}^{-1}$ )
$\left.\left.\mathrm{Fe}^{\mathrm{III}}\left[\mathrm{Fe}^{\mathrm{II}} \mathrm{CN}\right)_{5} \mathrm{NO}\right]-1 \mathrm{e}^{-} \rightleftarrows \mathrm{Fe}^{\mathrm{II}}\left[\mathrm{Fe}^{\mathrm{III}} \mathrm{CN}\right)_{5} \mathrm{NO}\right]($ at $0.85 \mathrm{~V}$ )

$\left.\left.\mathrm{Fe}^{\mathrm{III}}\left[\mathrm{Fe}^{\mathrm{III}} \mathrm{CN}\right)_{5} \mathrm{NO}\right]+2 \mathrm{X} \rightleftarrows \mathrm{Fe}^{\mathrm{III}}\left[\mathrm{Fe}^{\mathrm{II}} \mathrm{CN}\right)_{5} \mathrm{NO}\right]+\mathrm{Y}+2 \mathrm{H}^{+}$

where $\mathrm{X}=\mathrm{L}$-cys or $\mathrm{N}$-acy and $\mathrm{Y}=\mathrm{L}$ - cystine or $\mathrm{N}$-acetylcystine.

Thus L-cysteine and $\mathrm{N}$-acetylcysteine are electrocatalytically oxidized at the electrode surface and the oxidation process stars at $0.85 \mathrm{~V}$. Compared to L-cysteine or $\mathrm{N}$-acetylcysteine at the bare glassy carbon electrode this oxidation does not occur. The potential peak is not affected by sulfhydryl concentration and the catalytic current peak varies linearly with square root of the sweep rate. This indicates that the electrocatalytic process is controlled by diffusion.

The electrochemical behaviour of cysteine and $\mathrm{N}$ acetylcysteine oxidation of iron nitroprusside exhibit only one oxidation peak at $0.85 \mathrm{~V}$ ( $v s$. SCE), different from the Prussian Blue film modified electrode, that exhibits in the presence of cysteine and $\mathrm{N}$-acetylcysteine, two oxidation peaks at about 0.79 and $0.95 \mathrm{~V}$. $\left(1.0 \mathrm{~mol} \mathrm{~L}^{-1} \mathrm{KCl}, \mathrm{pH} 3.0 \mathrm{vs}\right.$. $\mathrm{Ag} / \mathrm{AgCl}) .{ }^{19}$

Also, differently from Prussian Blue ${ }^{19}$ whose film disintegrates by hydrolysis in solutions of $\mathrm{pH}$ higher than 5 , this hydrolysis with $\mathrm{Fe}(\mathrm{II}) \mathrm{NP}$ happens at $\mathrm{pH}>8$. The $\mathrm{Fe}(\mathrm{II}) \mathrm{NP}$ utility is limited only at $\mathrm{pH}<2.5$ because at higher concentration of protons an additional peak is present. ${ }^{17}$

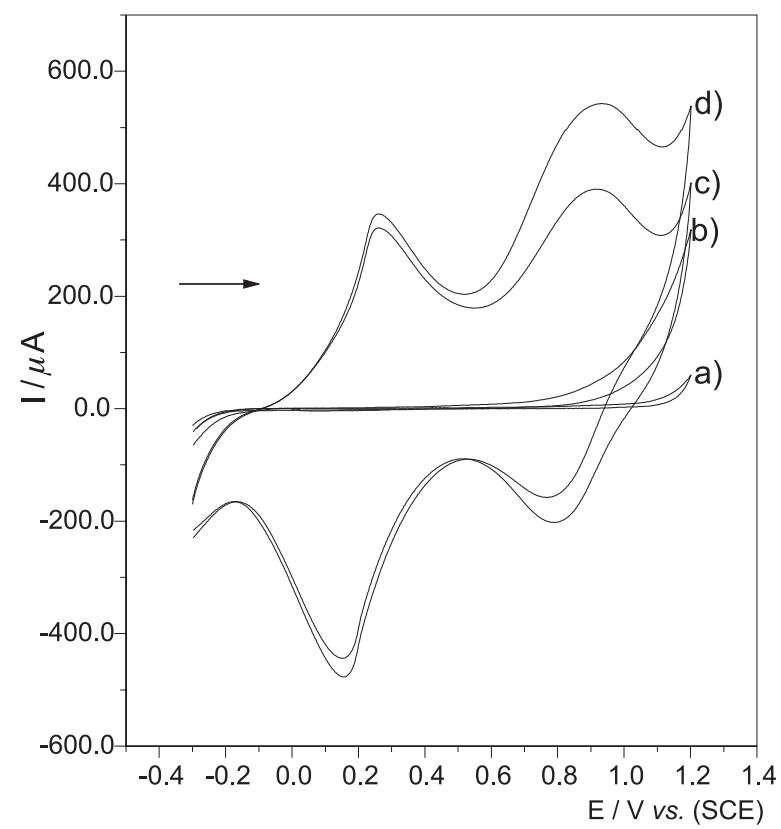

Figure 2. Cyclic voltammogram of: a) graphite paste electrode; b) graphite paste electrode in $4.2 \times 10^{-3} \mathrm{~mol} \mathrm{~L}^{-1} \mathrm{~N}$ - acetylcysteine; c) iron nitroprusside modified graphite paste electrode $(\mathrm{Fe}(\mathrm{II}) \mathrm{NP})$; d) modified electrode in $4.2 \times 10^{-3} \mathrm{~mol} \mathrm{~L}^{-1} \mathrm{~N}$ - acetylcysteine (1.0 mol L-1 $\mathrm{KCl} ; \mathrm{v}=20 \mathrm{mV} \mathrm{s}^{-1}$ ) 
Another important aspect of the electrocatalysys of sulfhydryl compounds is that the catalytic current decreases slightly with time after the first scan, probably due to depletion of sulfhydryl compounds ${ }^{19}$ near the electrode surface or the electrode is blocked by reaction products. ${ }^{20}$

Calibration graphs for the amount of sulphydryl compounds (L-cysteine and $\mathrm{N}$-acetylcysteine) versus anodic current are shown in Figures 3 and 4.

The modified electrode gives a linear responce from $9.2 \times 10^{-4}$ to $2.0 \times 10^{-2} \mathrm{~mol} \mathrm{~L}^{-1}(\mathrm{r}=0.998)$ and $9.6 \times 10^{-4}$ to $1.4 \times 10^{-2} \mathrm{~mol} \mathrm{~L}^{-1}(\mathrm{r}=0.997)$ for the determination of cysteine and $\mathrm{N}$-acetylcysteine, respectively, with detection limits of $1.9 \times 10^{-4} \mathrm{~mol} \mathrm{~L}^{-1}$ and $1.5 \times 10^{-4} \mathrm{~mol} \mathrm{~L}^{-1}$ and standard deviations of $5 \%$ and $4 \%(n=3)$ for L-cystine and $\mathrm{N}$-acetylcysteine, respectively. The amperometric sensitivities were 0.024 and $0.027 \mu \mathrm{A} / \mu \mathrm{mol} \mathrm{L}^{-1}$ for L-cysteine and $\mathrm{N}$-acetylcysteine.

The linear dependence of the calibration curve in Figures 3 and 4 suggests that the response of modified electrode is appropriated for quantitative L-cysteine and

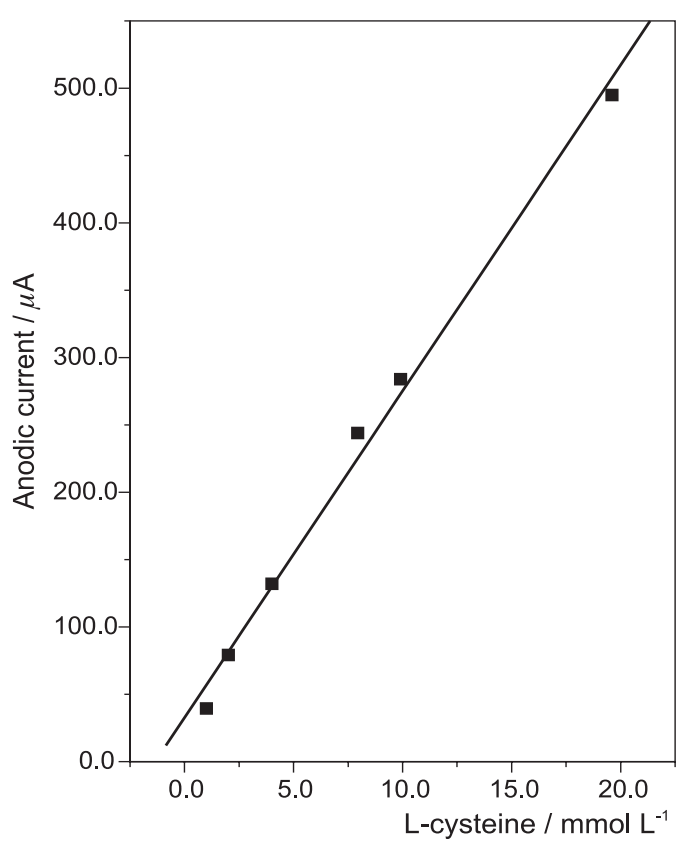

Figure 3. Calibration plot for determination of the L-cysteine $\left(1.0 \mathrm{~mol} \mathrm{~L}^{-1} \mathrm{KCl} ; \mathrm{v}=20 \mathrm{mV} \mathrm{s}^{-1}\right)$.
$\mathrm{N}$-acetylcysteine determination even in the millimolar concentration range. Such a wide concentration range of analytical useful response was also reported for L-cysteine determination by chemically modified electrodes. ${ }^{20}$

Similar to methods involving mercury electrodes, the calibration plot crosses the abscissa, presumably owing to the interference of trace heavy metal in supporting electrolytes ${ }^{21}$ but this does not interfere with the success for determination of sulfhyldryl compounds by addition methods. For L-cysteine determination the linear range and detection limit increase when comparated with Nacetylcysteine but the sensitivity is practically the same. The reproducibility is satisfactory for the investigated concentration range (RSD 5\% and $4.1 \%$ for L-cysteine and $\mathrm{N}$-acetilcysteine, respectively). The main electrochemical characteristic of iron nitroprusside modified paste electrode is that it could be re-used after an unique washing with Milli Q water, and it is not necessary to remove the electrode surface. Table 1 lists the main analytical parameters of these studies.

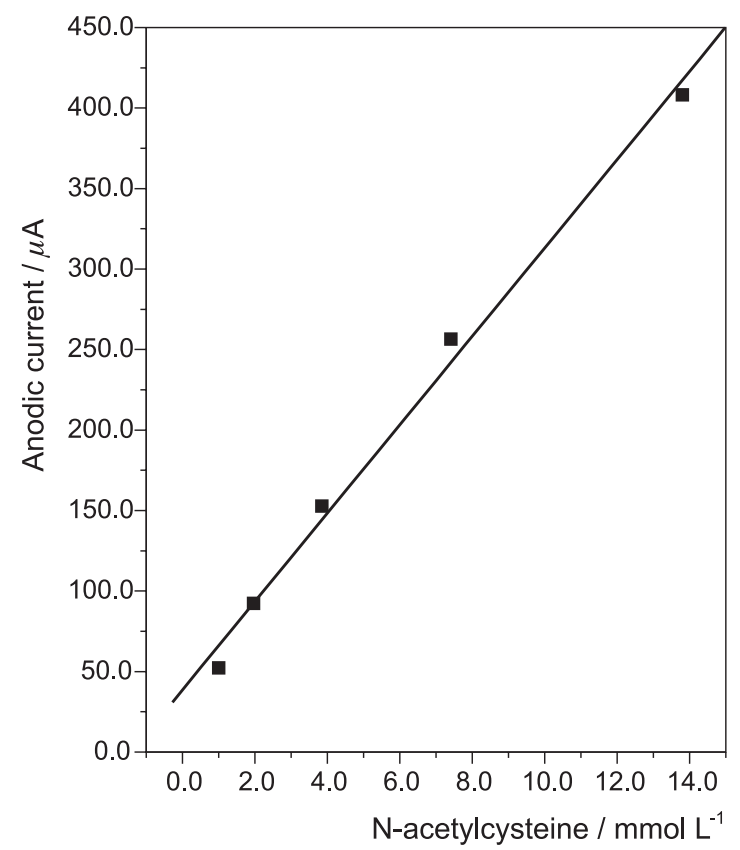

Figure 4. Calibration plot for determination of the $\mathrm{N}$-acetylcysteine $\left(1.0 \mathrm{~mol} \mathrm{~L}^{-1} ; \mathrm{v}=20 \mathrm{mV} \mathrm{s}^{-1}\right)$.

Table 1. Parameters of the calibration graph for sulfhydryl compounds determination

\begin{tabular}{lcccccc}
\hline Compounds & $\begin{array}{c}\text { Linear range } \\
(\mathrm{mol} \mathrm{L})^{-1}\end{array}$ & $\begin{array}{c}\text { Correlation } \\
\text { coefficient } \\
(\mathrm{r})\end{array}$ & $\begin{array}{c}\text { Detection } \\
\text { limit } \\
(\mathrm{mol} \mathrm{L}-1)\end{array}$ & $\begin{array}{c}\text { Amperometric } \\
\text { sensitivity } \\
\left(\mu \mathrm{A} / \mu \mathrm{mol} \mathrm{L}{ }^{-1}\right)\end{array}$ & Calibration equation & RSD \\
\hline L-cysteine & $9.2 \times 10^{-4}-2.0 \times 10^{-2}$ & 0.998 & $1.9 \times 10^{-4}$ & 0.024 & $\mathrm{I}(\mu \mathrm{A})=38.6+27.4[\mathrm{~L}-\mathrm{cysteine}]$ & \pm 0.050 \\
$\mathrm{~N}$ - acetylcysteine & $9.6 \times 10^{-4}-1.4 \times 10^{-2}$ & 0.997 & $1.5 \times 10^{-4}$ & 0.027 & $\mathrm{I}(\mu \mathrm{A})=32.9+24.2[\mathrm{~N}$-acetylcysteine] & \pm 0.041 \\
\hline $\mathrm{a}(\mathrm{n}=3)$. & & & & &
\end{tabular}




\section{Detemination of $N$-acetylcysteine in tablet}

Figure 5 shows the voltammograms of $\mathrm{Fe}(\mathrm{II}) \mathrm{NP}$ with addition of aliquots of Fluimucil and subsequent additions of $\mathrm{N}$-acetylcysteine solutions.

The standard addition method was applied for pharmaceutical product determination. The values obtained by this procedure $(205 \pm 0.4 \mathrm{mg})(\mathrm{n}=3)$ are comparable and agree well with the amount declared in these tablets $(200 \mathrm{mg})$.

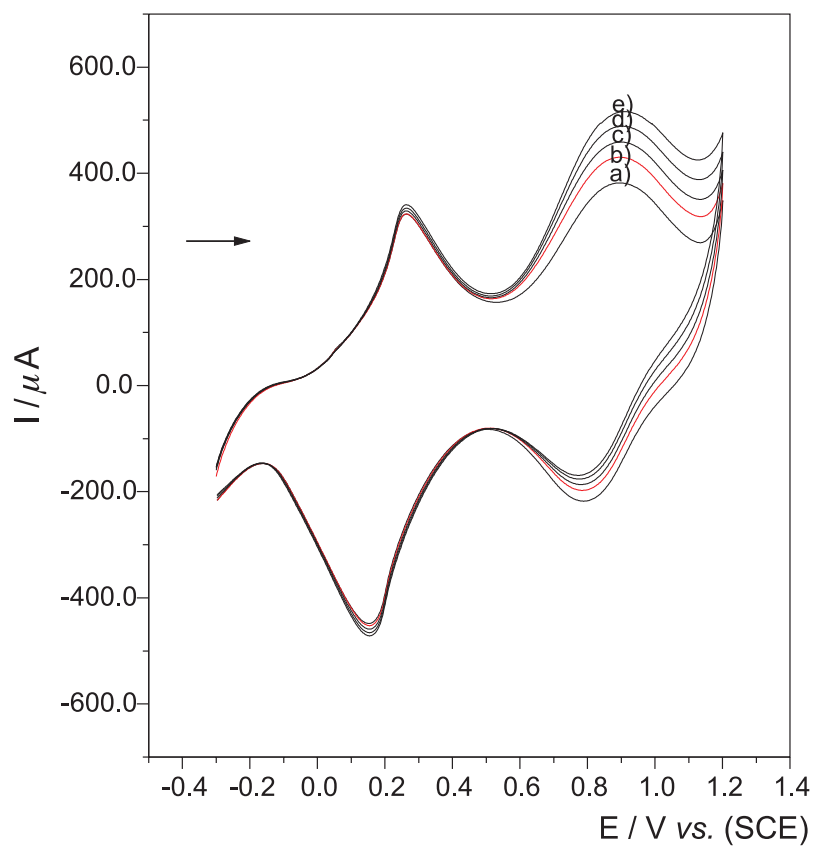

Figure 5. Determination of pharmaceutical product by addition method: a) iron nitroprusside modified graphite paste electrode (Fe(II)NP); b) modified electrode with additon of $500 \mu \mathrm{L}$ of Fluimucil; c,d,e,) additions of aliquots of $200 \mu \mathrm{L}$ of $\mathrm{N}$-acetylcysteine.

\section{Conclusions}

Iron nitroprusside, $\mathrm{Fe}(\mathrm{II}) \mathrm{NP}$, presents two redox couples at 0.24 and $0.85 \mathrm{~V}\left(\mathrm{KCl} 1.0 \mathrm{~mol} \mathrm{~L}^{-1} ; \mathrm{v}=20 \mathrm{mV} \mathrm{s}^{-1}\right.$ vs SCE). The voltammetric performance of insoluble solid incorporated in carbon paste electrode does not depend on pre-electrochemical treatment. The electrode preparation is simpler than the others processes of modification. An electrode surface renewal is not necessary as only a simple electrode washing is enough before each experiment. The electrode is chemically and electrochemically stable.

The second redox couple presents electrocatalytic property towards sulphydryl compounds. Quantitative determination in the millimolar range of $\mathrm{N}$-acetylcysteine in a pharmaceutical product (Fluimucil) can be achieved using Fe(II)NP incorporated in carbon paste electrode. This method is simple and convenient, and no separation step nor elimination of strange species is required.

\section{Acknowledgements}

The authors acknowledge FAPESP for financial support.

\section{References}

1. Ijeri,V.S.; Jaiswal, P.V.; Scrivastava, A.K.; Anal. Chim. Acta 2001, 439, 291

2. Wring, S.A.; Hart, J.P.; Analyst 1992, 117, 1215.

3. Mafatli,T.J.; Nyokong, I.; J.Electroanal.Chem. 1996, 408, 213.

4. Golabi, S.M.; Zare, H.R.; Hamzehloo, M.; Electroanalysis 2002, 14,611 .

5. Totir, N.; Luca C.; Lupu, S.; Lete, C.; Ion A.C.; Rev. Roum. Chim. 2001, 46, 555.

6. Haubey, A.C.; Malhotra, B.D.; Biosens. Bioelectron. 2002, 17, 441.

7. Razmi-Nerbin, H.; Pournaghi-Azar, M.H.; J. Solid State Electrochem. 2002, 6, 126.

8. Bergstron R.F.; Kay D.R.; Wagner J.E.; J. Chromatogr. 1981, $222,445$.

9. Jobll, M.E.; Williams D.G.; Johnson, D.C.; Electroanalysis 1997, 9, 1397

10. Shakaran, D.R.; Narayanan, S.S.; Bull. Electrochem. 1998, 4 , 267.

11. Chen,S.M.; J. Electroanal. Chem. 2002, 521, 29.

12. De Mattos I.L.; Gorton L.; Quim. Nova 2001, 24, 200.

13. De Toccani N.R.; K. Rajeshwar; Lesna, R.O.; Electrochim. Acta 2000, 45, 3403.

14. Garjonyté, R.; Malinauskas, A.; Sens. Actuators, B 1998, 46, 236.

15. Cui, X.P.; Hong L.; Lin X.Q.; Anal. Sci. 2002, 18, 543.

16. Ivanov, V.D.; Kaplum, M.M.; Russ. J. Electrochem. 1998 , 14, 559.

17. Do Carmo, D.R.; Da Silva, R.M.; Stradiotto, N.R.; Ecl. Quim. 2002, 27, 197

18. Ralph,T.R.; Hitchman, M.L.; Millington J.P.; Walsh F.C.; $J$. Electroanal. Chem. 1994, 375, 1.

19. Hou, W.; Wang, E.; J. Electroanal. Chem. 1991, 316, 155

20. Sãpataru, N.; Sarada, B.V.; Popa, E.; Tryk, D.A.; Fujishima, A.; Anal. Chem. 2001, 73, 514.

21. Florence, T.M.; J. Electroanal. Chem. 1979, 97, 237.

Received: February 19, 2003 Published on the web: August 14, 2003

FAPESP helped in meeting the publication costs of this article. 